\title{
HUBUNGAN NILAI MATA KULIAH PRASYARAT TERHADAP NILAI MATA KULIAH BIOKIMIA MAHASISWA PENDIDIKAN BIOLOGI UNIVERSITAS BORNEO TARAKAN
}

\section{The Correlation of The Result of Prerequisite Course and The Result of Biochemistry Course at The Students in Universitas Borneo Tarakan}

\author{
Fatmawati $^{\mathrm{a}^{*}}$ \\ a Program Studi Pendidikan Biologi, Universitas Borneo Tarakan, Tarakan, Kalimantan Utara \\ ${ }^{*}$ Corresponding author: J1. Amal Lama, Tarakan Timur, Tarakan, Kalimantan Utara, 77123, Indonesia. E-mail: \\ fatmawatibadawi@gmail.com
}

\begin{abstract}
Abstrak
Penelitian ini bertujuan untuk mengetahui hubungan nilai mata kuliah prasyarat terhadap nilai mata kuliah Biokimia mahasiswa Pendidikan Biologi Universitas Borneo Tarakan. Penelitian ini merupakan penelitian korelasi. Penetapan sampel menggunakan teknik sampling jenuh dengan subjek 97 mahasiswa. Pengumpulan data melalui observasi dan dokumentasi, data kemudian dianalisis menggunakan analisis korelasi. Hasil analisis korelasi diperoleh nilai signifikansi 0,032 dan nilai pearson correlation sebesar 0,218. Berdasarkan data tersebut, dapat disimpulkan bahwa nilai mata kuliah prasyarat memiliki hubungan positif dengan kategori rendah dan signifikan terhadap nilai mata kuliah Biokimia.
\end{abstract}

\section{Kata kunci}

Biokimia, Prasyarat

\begin{abstract}
The aim of this research is to know the correlation of the result of prerequisite course and the result of Biochemistry at the students in Universitas Borneo Tarakan. This research was correlation research. The sampling method used observation and documentation, and then data collected in the research that is analyzed used analysis of correlation. The result of analysis showed significant 0,032 and the value of Pearson correlation was 0,218. Based on the data, The result of prerequisite course have positive correlation (with low category) to the result of Biochemistry
\end{abstract}

\section{Keywords}

Biochemistry, prerequisite 


\section{Pendahuluan}

Cakupan biokimia meliputi protein, karbohidrat, lipid, makromolekul lainnya berikut proses metabolisme serta yang terkait. Secara garis besar biokimia terkait proses kimiawi yang berlangsung di dalam tubuh manusia serta bahan makanan dan sumber-sumbernya (Poedjiadi et al. 2007). Diperlukan pemahaman dasar terkait kimia dan biologi untuk pemantapan mata kuliah tersebut karena jika ingin memahami proses secara lengkap yang terjadi didalam tubuh maka pembahasannya sampai ke tingkat seluler dan molekuler. Berdasarkan cakupan biokimia tersebut maka efisiensi dalam memahami materi perlu diperhatikan terutama penyajiannya di bangku perkuliahan. Jika melihat konten dan satuan kredit semester (SKS) yang pada umumnya diterapkan di Kurikulum maka penyajian materi belum mampu tersampaikan secara menyeluruh.

Memadukan antara isi materi dan SKS dapat disikapi dengan pemangkasan materi atau penerapan mata kuliah prasyarat yaitu mata kuliah yang perlu ditempuh sebelum pengambilan mata kuliah tertentu. Mata kuliah prasyarat dapat dipilih atau menjadi pilihan karena selain sistematis langkah ini juga dapat memberi pemahaman yang mendalam kepada peserta didik. Sebagian jurusan atau program studi yang pada kurikulumnya terdapat MK biokimia menetapkan MK prasyarat baik secara tertulis ataupun non tertulis bahkan terdapat jurusan yang menetapkan prasayarat berjejang untuk MK Biokimia.

Kebijakan mata kuliah prasyarat juga diterapkan di jurusan Biologi Universitas Borneo Tarakan. Terdapat mata kuliah yang dipandang perlu untuk dijalani sebelum menempuh MK Biokimia, MK tersebut yaitu Kimia Dasar yang ditempatkan pada semester I dan Biokimia pada semester III. Mata Kuliah Kimia Dasar disusun sedemikian rupa sehingga didalamnya termuat pengantar dasar-dasar kimia baik kimia organik dasar maupun pengantar biokimia dengan tujuan dapat memudahkan peserta didik melanjutkan materi ketika menempuh Biokimia di semester selanjutnya, Suhandiah \& Hariadi (Kirana, 2018) mengungkapkan bahwa kesinambungan didalam pembelajaran dapat memberikan pengalaman pelajaran yang akan berguna pada saat mengikuti pelajaran yang akan ditempuh berikutnya.

Banyak peserta didik yang dapat mengambil MK Biokimia karena dianggap telah memenuhi syarat untuk mengambil MK tersebut, tapi tidak sedikit pula peserta didik yang tidak dapat mengambil karena rendahnya nilai Kimia Dasar yang diperoleh. MK Biokimia penting untuk diajarkan dan dipelajari terutama pada jurusan Biologi karena MK ini berkaitan dengan MK lainnya pada kurikulum Biologi seperti Biologi Sel, Biomolekul dan Genetika. Selain karena alasan keterkaitan beberapa MK tersebut, peranannya pada bidang kesehatan juga menjadi daya tarik mata kuliah biokimia, namun peranan tersebut tidak menjadikan mata kuliah biokimia mudah untuk dipahami. Hal tersebut terlihat pada saat proses pembelajaran dan nilai hasil belajar yang diperoleh peserta didik.

Pada saat proses pembelajaran, peserta didik tampak berusaha untuk memahami dan materi kerap di lakukan pembahasan berulang. Selain itu, terdapat beberapa peserta didik yang masih belum berada pada nilai yang diharapkan dimana sebagian peserta didik berada pada rentang 50-60 dengan predikat $\mathrm{D}$ atau $\mathrm{C}$, namun jika ditinjau secara keseluruhan maka skor terbanyak diperoleh pada rentang 70-79 dengan predikat $\mathrm{A}$ atau $\mathrm{AB}$.

Anwar, Junaidi \& Al Idrus (2018) mengungkapkan bahwa Pemahaman konsep biokimia membutuhkan ketrampilan berpikir tingkat tinggi sehingga pendekatan yang diperlukan adalah pendekatan yang mampu melatih kemampuan tersebut, Namun, yang terjadi di kelas mahasiswa belum terlatih untuk mengembangkan kemampuan menganalisis materi.Selanjutnya hasil penelitian Anwar et al. (2018) menunjukkan materi pokok dogma 


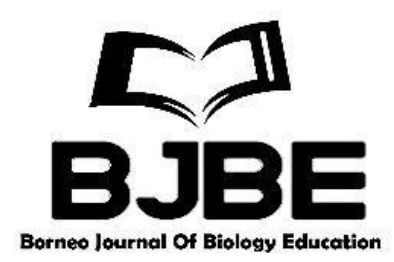

pusat dan enzim adalah materi pokok yang paling banyak mengalami kesalahan konsep yaitu sebesar 58,89\% dan 42,20\% pada mata kuliah Biokimia I. Sedangkan mata kuliah Biokimia II mengalami kesalahan konsep pada materi pokok struktur karbohidrat, glikolisis, struktur asam lemak dan reaksi yaitu berturut-turut $62,2 \% ; 64,4 \% ; 66,67 \%$ dan $77,78 \%$.

\section{Material dan metode}

Penelitian dilakukan pada semester Ganjil pada Tahun Akademik 2018/2019. Penelitian dilakukan pada Jurusan pendidikan Biologi Fakultas Keguruan dan Ilmu Pendidikan Universitas Borneo Tarakan. Populasi penelitian yaitu peserta didik angkatan 2017 Jurusan pendidikan Biologi Fakultas Keguruan dan Ilmu Pendidikan Biologi Universitas Borneo Tarakan yang telah menempuh mata kuliah biokimia berjumlah 97 peserta didik. Sampel penelitian yakni peserta didik angkatan 2017 Jurusan pendidikan Biologi Fakultas Keguruan dan Ilmu Pendidikan Biologi Universitas Borneo Tarakan yang telah menempuh mata kuliah biokimia berjumlah 97 peserta didik.

Teknik sampling yang dipilih adalah teknik sampling jenuh yaitu seluruh peserta didik angkatan 2017 Jurusan Pendidikan Biologi Universitas Borneo Tarakan Yang berjumlah 98 peserta didik, Martono (Karina, Syafrina, \& Habibah, 2017) mengungkapkan bahwa sampling jenuh merupakan teknik penentuan sampel yang menggunakan semua anggota populasi sebagai sampel.

Penelitian ini termasuk jenis penelitian korelasional, Kegunaan Korelasi yaitu untuk mengetahui derajat hubungan antara variabel bebas (independent) dengan variabel terikat (dependent) (Riduwan \& Kuncoro, 2008). Data dalam penelitian Korelasi ini menggunakan SPSS Statistics 17.0 untuk menentukan deskripsi data dan hubungan (korelasi) antar variabel. Analisis data digunakan pendekatan deskriptif kuantitatif, pendekatan kuantitatif merupakan pendekatan dimana data yang dikumpulkan berupa data kuantitatif atau jenis data lain yang dapat dikuantitatifkan dan diolah dengan menggunakan teknik statistik (Yusuf, 2017).

Teknik yang diterapkan dalam pengumpulan data yaitu dengan observasi dan dokumentasi berupa nama peserta didik, nilai hasil belajar kimia dasar dan nilai hasil belajar mata kuliah biokimia Tahun Akademik 2018/2019. Teknik analisis data yang digunakan yaitu analisis deskriptif dan analisis inferensial. Analisis deskriptif bertujuan untuk penentuan tendensi sentral diantaranya mean, median, standar deviasi dan frekuensi data. Analisis inferensi yang digunakan untuk menguji hipotesis yaitu Korelasi Pearson Product Moment (PPM), variabel yang diuji adalah Nilai Mata Kuliah Prasyarat (X) terhadap Nilai Mata Kuliah Biokimia (Y) sebagaimana berikut:

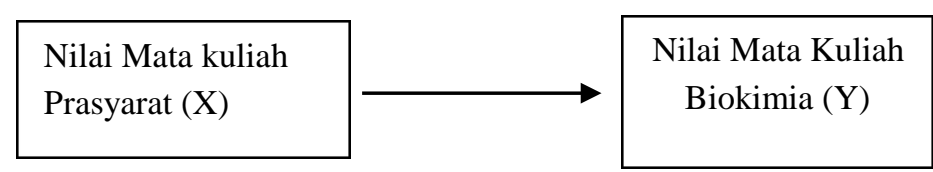

Gambar 1. Variabel Independen dan Variabel Dependen

\section{Hasil dan Diskusi}

Hasil deskripsi data dengan menggunakan SPSS 17.0 for windows untuk mata kuliah kimia dasar (variabel bebas) diperoleh Mean sebesar 65,50, Median sebesar 64,00, dan Standar Deviasi sebesar 9,54. Pada mata kuliah biokimia (variabel terikat) diperoleh Mean, Median, dan Standar Deviasi berturut-turut sebesar 71, 23; 71,00 dan 4,34. Sebaran nilai hasil 


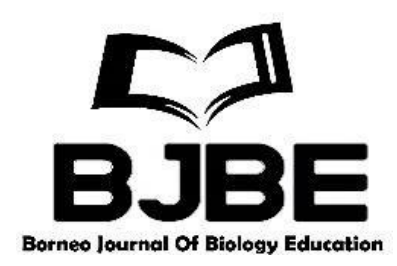

belajar peserta didik jurusan Pendidikan Biologi Angkatan 2017 Fakultas Keguruan dan Ilmu Pendidikan Universitas Borneo Tarakan dapat dilihat melalui Tabel 1. sebagai berikut.

Tabel 1. Sebaran Nilai Jurusan Pendidikan Biologi Angkatan 2017 FKIP Universitas Borneo Tarakan

\begin{tabular}{cccc}
\hline Interval & Kimia Dasar & Frekuensi & Kategori \\
\hline $80-100$ & 8 & Biokimia & $\mathrm{A}$ \\
$75-79$ & 8 & 1 & $\mathrm{AB}$ \\
$70-74$ & 11 & 17 & $\mathrm{~B}$ \\
$65-69$ & 21 & 50 & $\mathrm{BC}$ \\
$60-64$ & 28 & 28 & $\mathrm{C}$ \\
$55-59$ & 14 & - & $\mathrm{CD}$ \\
$40-54$ & 5 & - & $\mathrm{D}$ \\
$\mathrm{x}<40$ & 2 & 1 & $\mathrm{E}$ \\
\hline
\end{tabular}

Penentuan kategori penilaian mengacu pada standar nilai yang ditetapkan oleh pihak Universitas Borneo Tarakan yaitu terdiri atas A, AB, B, BC, C, CD, D dan E. Berdasarkan tabel sebaran nilai jurusan Pendidikan Biologi Angkatan 2017 Fakultas Keguruan dan Ilmu Pendidikan (FKIP) Universitas Borneo Tarakan, untuk urutan interval dan kategori yang diperoleh peserta didik pada mata kuliah kimia dasar dari terbesar ke terkecil yaitu interval 6064 yang jumlah 28 peserta didik dengan kategori C; 65-69 yang berjumlah 21 orang dengan kategori $\mathrm{BC}$; 55-59 berjumlah 14 orang dengan kategori $\mathrm{CD}$; 70-74 berjumlah 11 orang kategori B; 80-100 kategori A dan 75-79 kategori AB diraih oleh peserta didik dengan jumlah yang sama yaitu masing-masing 8 orang; 40-54 kategori D sejumlah 5 orang dan hanya 2 orang yang memiliki nilai kurang dari 40 atau kategori E. Jadi, frekuensi terbesar pada mata kuliah kimia dasar yaitu berada pada interval 60-64 dengan kategori $\mathrm{C}$ atau dengan kata lain peserta didik terbanyak meraih nilai dengan kategori C. Sedangkan pada Pada MK biokimia jika diurutkan dari yang terbesar ke yang terkecil sesuai interval dan jumlah peserta didik yang meraih nilai biokimia maka urutan kategori tersebut yakni B, BC, AB, dan A serta D diraih oleh peserta didik dengan jumlah yang sama yaitu 1 orang sementara tidak terdapat peserta didik yang memperoleh nilai dengan kategori $\mathrm{C}, \mathrm{CD}$ dan E. Jadi, nilai biokimia yang paling banyak diraih peserta didik berada pada rentang 70-74 dengan kategori B.

Uji hipotesis dilakukan melalui analisis korelasi berbantuan SPSS 17.0 for windows dengan taraf signifikansi 0,05. Adapun pengajuan hipotesis (Riduwan \& Kuncoro, 2008) sebagai berikut:

1. Ha : Variabel $\mathrm{X}$ berhubungan secara signifikan dengan variabel $\mathrm{Y}$

2. Ho : Variabel $\mathrm{X}$ tidak berhubungan secara signifikan dengan variabel $\mathrm{Y}$

Dasar pengambilan keputusan (Riduwan \& Kuncoro, 2008) sebagai berikut:

1. Jika nilai probabilitas 0,05 lebih kecil atau sama dengan nilai probabilitas Sig atau $[0,05$ $\leq$ Sig], maka Ho diterima dan Ha ditolak, artinya tidak signifikan

2. Jika nilai probabilitas 0,05 lebih besar atau sama dengan nilai probabilitas Sig atau $[0,05$ $\geq$ Sig], maka Ho ditolak dan Ha diterima, artinya signifikan

Data hasil uji korelasi pengujian variabel $\mathrm{X}$ terhadap $\mathrm{Y}$ sesuai tujuan penelitian yaitu nilai hasil belajar kimia dasar terhadap nilai hasil belajar biokimia. Hasil analisis menggunakan SPSS 17.0 for windows dapat dilihat pada Tabel 2 sebagai berikut: 


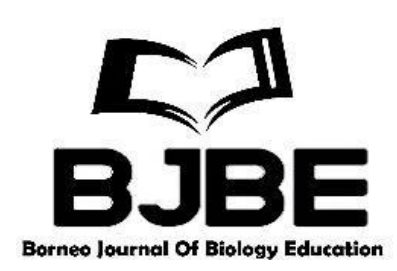

Tabel 2. Data Korelasi Variabel X terhadap Variabel Y

\begin{tabular}{llrr}
\hline & & $\begin{array}{c}\text { Nilai Matakuliah } \\
\text { Kimia Dasar }\end{array}$ & $\begin{array}{c}\text { Nilai Mata Kuliah } \\
\text { Biokimia }\end{array}$ \\
\hline Nilai Mata Kuliah & Pearson Correlation & 1 & 0.218 \\
Kimia Dasar & Sig (2 tailed) & & 0.032 \\
& N & 97 & 97 \\
Nilai Mata Kuliah & Pearson Correlation & 0.218 & 1 \\
Biokimia & Sig (2 tailed) & 0.032 & \\
& N & 97 & 97 \\
\hline
\end{tabular}

Berdasarkan analisis korelasi, diperoleh data sebagaimana pada Tabel. dimana nilai Sig. (2tailed) bernilai 0,032. Angka tersebut lebih kecil daripada nilai probabilitas yaitu 0,05 atau nilai $0,05>0,032$, hal tersebut membuktikan bahwa Ho ditolak dan Ha diterima yang berarti bahwa variabel $\mathrm{X}$ berhubungan secara signifikan dengan variabel Y. Jadi dapat ditarik kesimpulan bahwa nilai hasil belajar kimia dasar peserta didik berhubungan secara signifikan terhadap nilai hasil belajar biokimia peserta didik tersebut. Kategori hubungan (korelasi) ditentukan dengan kategori koefisien oleh Arifin (Karina, syafrina, \& Habibah, 2017) pada tabel 3. berikut:

Tabel 3. Kategori Hubungan (korelasi)

\begin{tabular}{cc}
\hline Interval (r) Product Moment & Interpretasi \\
\hline $0,00-0,20$ & Sangat Rendah \\
$0,21-0,40$ & Rendah \\
$0,41-0,60$ & sedang \\
$0,61-0,80$ & Tinggi \\
$0,81-1,00$ & Sangat Tinggi \\
\hline
\end{tabular}

Pada Tabel 2 diperoleh pearson correlation sebesar 0,218. Sesuai tabel, angka tersebut berada pada interval 0,21-0,40 dengan interpretasi rendah yang bermakna bahwa hubungan nilai hasil belajar kimia dasar dengan biokimia yaitu dengan kategori rendah atau kekuatan hubungan berada pada kategori rendah. Hubungan memiliki arah positif yang ditunjukkan oleh nilai postif dari nilai pearson correlation sebesar 0,218.

Terdapat hubungan mata kuliah prasyarat terhadap mata kuliah biokimia. Mata kuliah prasyarat dapat berpengaruh terhadap mata kuliah lanjutan prasyarat, hal tersebut sejalan dengan penelitian Septian (2014) bahwa: (1) Terdapat hubungan positif dan signifikan antara kemampuan prasyarat dengan kemampuan penalaran matematis mahasiswa dalam matakuliah Analisis Real; dan (2) Terdapat pengaruh signifikan kemampuan prasyarat terhadap kemampuan penalaran matematis mahasiswa dalam matakuliah Analisis Real.

Hubungan nilai hasil belajar mata kuliah kimia dasar terhadap nilai hasil belajar biokimia yaitu signifikan. Kimia dasar merupakan mata kuliah yang memuat dasar-dasar pembelajaran kimia dan dasar-dasar kimia perlu diperdalam karena dapat terkait dengan bahan kajian ilmu kimia yang lainnya atau kimia lanjutan seperti biokimia, keterkaitan kimia dasar dan biokimia digambarkan melalui buku yang dikembangkan oleh Sastrohamidjojo (2018) dimana buku kimia dasar yang disusun dapat memberikan wawasan yang luas disertai contohcontoh soal yang dapat dikembangkan, misal untuk mempelajari Biokimia, Kimia Organik Lanjut, dan sebagainya. Biokimia penting untuk diajarkan dan dipelajara terutama pada jurusan pendidikan Biologi karena ilmu ini berkaitan dengan mata kuliah pada 


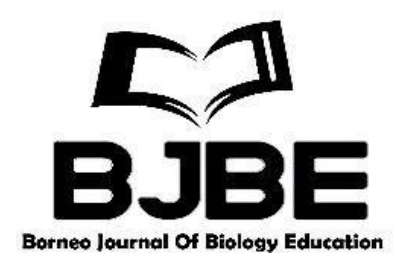

kurikulum biologi seperti genetika, fisiologi, mikrobiologi, botani dan zoologi. Sebagai salah satu kualifikasi dari lulusan pendidikan biologi yaitu menjadi tenaga pendidik sudah tentu syarat-syarat lulusan pendidikan biologi perlu dimiliki termasuk penguasaan konsep pada mata kuliah yang diampu. Peranan ilmu biokimia pada jurusan Pendidikan Biologi FKIP UBT tertuang pada kurikulum pendidikan biologi (Tim Penyusun Kurikulum Pendidikan Biologi UBT, 2017) dimana Biokimia merupakan salah satu mata kuliah yang wajib ditempuh oleh peserta didik sebelum menyelesaikan kelulusan sebagai sarjana pendidikan biologi.

Selain nilai Sig. (2-tailed) untuk menyatakan hubungan antara dua variabel yaitu kimia dasar dan biokimia, nilai pearson correlation juga dapat memberikan deskripsi tentang hubungan kedua variabel. Nilai pearson correlation yaitu 0,218 berada pada interval 0,21

- 0,40 dengan interpretasi rendah yang bermkana bahwa kekuatan hubungan kedua variabel adalah rendah. Meskipun demikian, nilai positif dari 0,218 menunjukkan bahwa kedua variabel memiliki hubungan positif yaitu kenaikan nilai hasil belajar kimia dasar berperan pada kenaikan nilai hasil belajar biokimia, penarikan kesimpulan tersebut sejalan dengan model hasil penelitian Irfan \& Suprapti (2014) yaitu hasil korelasi dalam penelitian yang dilakukan menunjukkan bahwa terdapat hubungan positif antara self-efficacy dengan penyesuaian diri terhadap perguruan tinggi, hal ini menunjukkan bahwa semakin tinggi self- efficacy seseorang maka semakin tinggi level penyesuaian diri terhadap perguruan tinggi.

Kontribusi nilai hasil belajar kimia dasar terhadap nilai hasil belajar biokimia dapat ditentukan dengan perhitungan manual yang dikemukakan oleh Pallant (Irfan \& Suprapti, 2014) untuk mengetahui persentase varian antar dua variabel, cara tersebut yaitu koefisien korelasi dikuadratkan lalu dikali $100 \%$. Hasil perhitungan manual dari kofisien korelasi 0,218 diperoleh persentase sebesar 4,75\%. Hasil perhitungan tersebut menunjukkan bahwa nilai hasil belajar kimia dasar berkontribusi sebesar $4,75 \%$ terhadap nilai hasil belajar biokimia atau dengan kata lain bahwa nilai hasil belajar biokimia dipengaruhi oleh 4,75\% dari nilai hasil belajar kimia dasar dan sisanya yaitu sebesar 95,25\% dipengaruhi oleh faktor lain. Suryabrata (Aritonang, 2008) mengungkapkan bahwa terdapat berbagai faktor yang mempengaruhi nilai hasil belajar. Faktor-faktor yang mempengaruhi hasil belajar digolongkan menjadi tiga, yaitu: faktor dari dalam, faktor dari luar, dan faktor instrumen.

Faktor dari dalam yaitu faktor-faktor yang dapat mempengaruhi belajar yang berasal dari siswa yang sedang belajar. Faktor-faktor ini diantaranya adalah: (a) minat individu merupakan ketertarikan individu terhadap sesuatu. (b) motivasi belajar antara siswa yang satu dengan siswa lainnya tidaklah sama. Motivasi belajar dipengaruhi oleh beberapa faktor, antara lain: cita-cita siswa, kemampuan belajar siswa, kondisi siswa, kondisi lingkungan, unsur-unsur dinamis dalam belajar, dan upaya guru membelajarkan siswa. Faktor dari luar yaitu faktorfaktor yang berasal dari luar siswa yang mempengaruhi proses dan hasil belajar. Faktor-faktor ini di antaranya adalah lingkungan sosial. Faktor instrumen yaitu faktor yang berhubungan dengan perangkat pembelajaran seperti kurikulum, struktur program, sarana dan prasarana pembelajaran (media pembelajaran), serta guru sebagai perancang pembelajaran.

\section{Kesimpulan}

Berdasarkan hasil analisis data, pada taraf signifikansi 0,05 diperoleh nilai koefisien korelasi sebesar 0,032. Nilai koefisien korelasi tersebut menunjukkan Ha diterima yang berarti nilai mata kuliah prasyarat berhubungan secara signifikan dengan nilai mata kuliah Biokimia. Nilai Pearson Correlation sebesar 0,218 menandakan terdapat hubungan positif pada tingkat rendah antara nilai mata kuliah prasyarat dengan nilai mata kuliah Biokimia. 


\section{Daftar Pustaka}

Anwar, Y. A. S., Junaidi, E., \& Al Idrus, S. W. (2014). Analisis Kesulitan Belajar Biokimia Mahasiswa Dalam Upaya Pengembangan Perangkat Pembelajaran Berbasis Daur Belajar Johnston. Jurnal Kajian Penelitian dan Pengembangan Kependidikan Vol.5 No.1

Aritonang, K. T. (2008). Minat dan Motivasi dalam Meningkatkan Hasil Belajar Siswa. Jurnal Pendidikan Penabur - No.10/Tahun ke-7/Juni 2008

Irfan, M. \& Suprapti,V. (2014). Hubungan Self-efficacy dengan Penyesuaian Diri Terhadap Perguruan Tinggi pada Mahasiswa Baru Fakultas Psikologi Universitas Airlangga. JURNAL Psikologi Pendidikan dan Perkembangan Volume 3, No. 3, Desember 2014

Karina, R. M., Syafrina, A., \& Habibah, Sy. (2017). Hubungan Antara Minat Belajar dengan Hasil Belajar Siswa dalam Mata Pelajaran IPA pada Kelas V SD Negeri Garot Geuceu Aceh Besar. Jurnal Ilmiah Pendidikan Guru Sekolah Dasar FKIP Unsyiah Volume 2 Nomor 1, 61-77 Januari 2017.

Kirana, C. C. (2018). Hubungan dan Pengaruh Nilai Mata Kuliah Prasyarat terhadap Nilai Mata Kuliah Mekanika pada Mahasiswa Pendidikan Fisika FKIP UNSYIAH. Skripsi.

Poedjiadi, A. \& Supriyanti, F.M. Titin. (2007). Dasar-dasar Biokimia. Jakarta: Universitas Indonesia (UI-Press).

Riduwan \& Kuncoro, E. A. (2008). Cara Menggunakan dan Memaknai Analisis Jalur (Path Analysis). Bandung: Alfabeta.

Sastrohamidjojo, H. (2018). Kimia Dasar. Yogyakarta: Gadjah Mada University Press.

Septian, A. (2014). Pengaruh Kemampuan Prasyarat terhadap Kemampuan Penalaran Matematis Mahasiswa dalam Matakuliah Analisis Real. Jurnal Kajian Pendidikan, 4(2).

Tim Penyusun Kurikulum Pendidikan Biologi UBT. (2017). Kurikulum Jurusan Pendidikan Biologi Fakultas Keguruan dan Ilmu Pendidikan Universitas Borneo Tarakan.

Yusuf, A. M. (2017). Metode Penelitian Kuantitatif, Kualitatif \& Penelitian Gabungan. Jakarta: Kencana 